\title{
NPR-A gene deletion reverses vascular dysfunction associated with
}

\section{sepsis}

\section{Catherine M Panayiotou* and Adrian J Hobbs}

Address: Wolfson Institute for Biomedical Research, University College London, WC1E 6AE, UK

Email: Catherine M Panayiotou* - catherine.panayiotou@ucl.ac.uk

* Corresponding author

from $3^{\text {rd }}$ International Conference on cGMP Generators, Effectors and Therapeutic Implications

Dresden, Germany. 15-17 June 2007

Published: 25 July 2007

BMC Pharmacology 2007, 7(SuppI I):P44 doi:I0.II86/I47I-22I 0-7-SI-P44

This abstract is available from: http://www.biomedcentral.com/I47I-22I0/7/SI/P44

(c) 2007 Panayiotou and Hobbs; licensee BioMed Central Ltd.

\section{Background}

Natriuretic peptides are a family of hormone/paracrine factors that play important roles in cardiovascular homeostasis. Atrial natriuretic peptide (ANP) and brain natriuretic peptide (BNP), produced in the heart, bind to the particulate quanylate cyclase (pGC) linked natriuretic peptide receptor A (NPR-A) and generate the intracellular messenger cyclic guanosine 3',5'-monophosphate (cGMP). Via this receptor, ANP/BNP cause vasodilatation and natriuresis, and are important in the regulation of blood pressure; mice lacking NPR-A exhibit hypertension and cardiac hypertrophy [1]. Since many cardiovascular disorders, including atherosclerosis and septic shock, are now accepted as inflammatory diseases of the vessel wall, elucidating potential roles for natriuretic peptides in regulating vascular inflammation could assist in the prevention and treatment of cardiovascular disease.
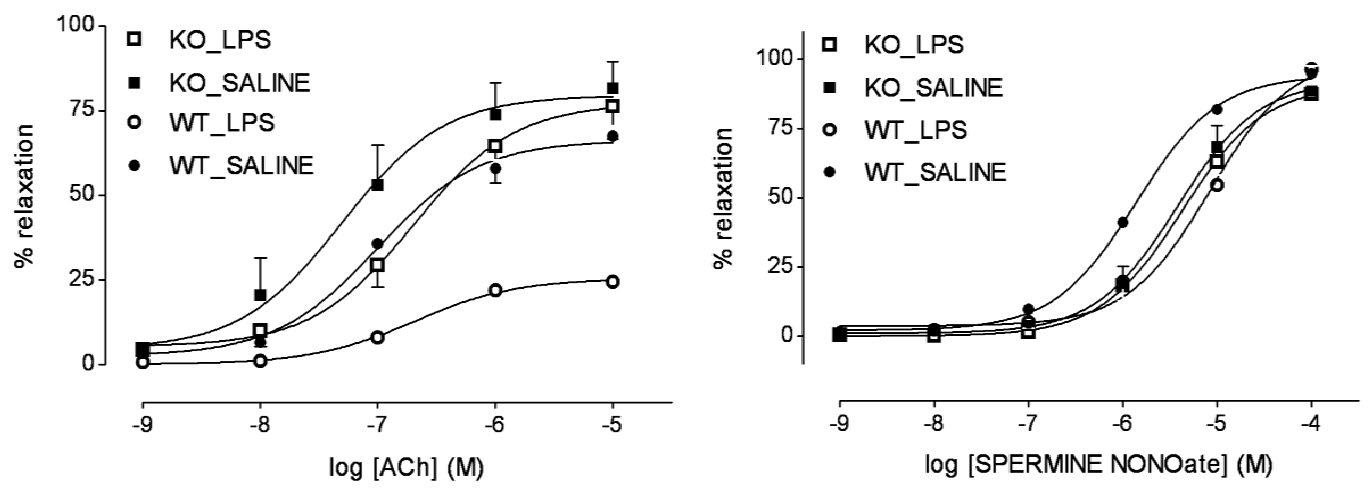

Figure I

Concentration-response curves to ACh (left) and SPER-NO (right) in aortic rings from WT and NPR-A KO mice treated with LPS (I $2.5 \mathrm{mg} / \mathrm{kg}$. i.v.) or saline for $16 \mathrm{~h}$. Relaxation is expressed as mean \pm SEM percentage reversal of U466 I 9-induced tone ( $\mathrm{n}$ = 3-9). 


\section{Materials and methods}

Male NPR-A knockout (KO) or wild type (WT; C57BL6) mice (25-30 g) were treated with $12.5 \mathrm{mg} / \mathrm{kg}$ i.v. Salmonella typhimurium lipopolysaccharide (LPS) or vehicle. After $16 \mathrm{~h}$ tissues (lung, aorta) were snap frozen and analysed for iNOS expression by western blot; plasma $\mathrm{NO}_{\mathrm{x}}$ was measured by chemiluminescence. Endothelial and vascular (dys)function were assessed in isolated aortic rings using organ bath pharmacology. Vessels were precontracted with an $\sim \mathrm{EC}_{80}$ concentration of U46619 and concentration-response curves constructed to spermine NONOate (SPER-NO; $\left.10^{-9}-10^{-4} \mathrm{M}\right)$, ANP $\left(10^{-11}-10^{-6} \mathrm{M}\right)$, and acetylcholine (ACh; $10^{-9}-10^{-5} \mathrm{M}$ ).

\section{Results}

LPS administration in vivo caused a greater suppression of responses to U46619, ACh, ANP and SPER-NO in WT animals compared to NPR-A KO mice (Fig. 1). This differential effect on vascular function was paralleled by reduced iNOS expression (lung: $38.5 \pm 6.3 \% *$ decrease, aorta: 80.3 $\pm 10.2 \%{ }^{*}$ decrease; ${ }^{*} P<0.05$ vs saline control) and activity (plasma $\left[\mathrm{NO}_{\mathrm{x}}\right]$ : WT saline $53.10 \pm 5.156 \mu \mathrm{M}$, WT LPS $597.7 \pm 34.98 \mu \mathrm{M}$, NPR-A KO saline $45.55 \pm 6.054 \mu \mathrm{M}$, NPR-A KO LPS $387.2 \pm 22.36 \mu \mathrm{M}^{*} ; \mathrm{n}=7 ;{ }^{*} \mathrm{P}<0.05$ vs WT).

\section{Conclusion}

Deletion of NPR-A in vivo results in reduced iNOS expression and vascular dysfunction associated with endotoxaemia. These data suggest that NPR-A activation (by ANP and/or BNP) can function as a pro-inflammatory mechanism that might assist in facilitating host defence in response to infection.

\section{Acknowledgements}

This work was supported by The Wellcome Trust.

\section{References}

I. Oliver PM, Fox JE, Kim R, Rockman HA, Kim HS, Reddick RL, et al.: Hypertension, cardiac hypertrophy, and sudden death in mice lacking natriuretic peptide receptor $\mathbf{A}$. Proc Natl Acad Sci 1997, 94: 14730-I4735.

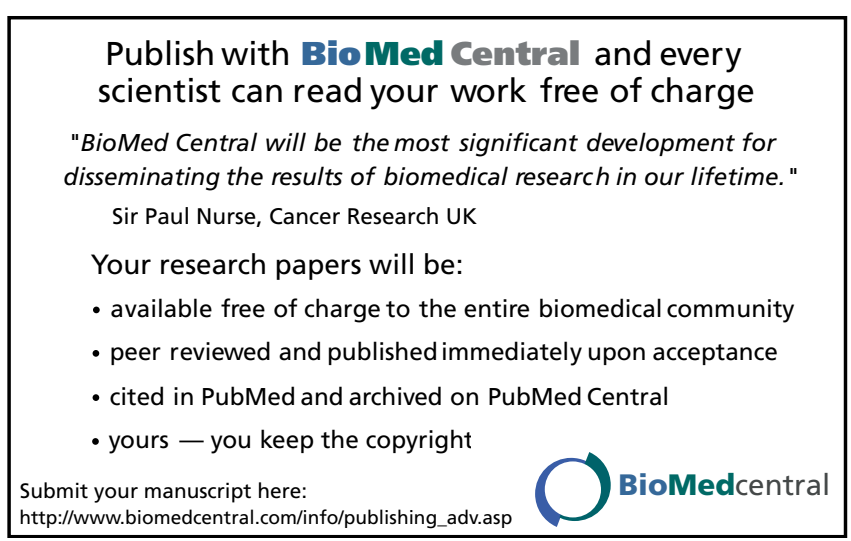

